\title{
BIOREFINERY FOR SEQUENTIAL EXTRACTION OF FUCOIDAN AND ALGINATE FROM BROWN ALGA Sargassum cristaefolium
}

\author{
Sugiono Sugiono $^{1 \bowtie}$, Doni Ferdiansyah $^{1}$ \\ ${ }^{1}$ Department of Fisheries Science, Faculty of Agriculture, Madura Islamic University, Pamekasan 69351, \\ Indonesia \\ 凶yonosugiono78@yahoo.co.id \\ https://doi.org/10.34302/crpjfst/2020.12.2.9

\begin{tabular}{|c|c|}
\hline Article history: & ABSTRACT \\
\hline $\begin{array}{l}\text { Received: } \\
\text { 27 June } 2019 \\
\text { Accepted: } \\
\quad 22 \text { March } 2020 \\
\end{array}$ & $\begin{array}{l}\text { The critical step in the sequential extraction of fucoidan and alginate from } \\
\text { brown algae is acid treatment, since it noticeably affects physicochemical } \\
\text { properties of the both components. This study aimed to investigate the effects } \\
\text { of acid treatment on the multiple responses of alginate and fucoidan yield from }\end{array}$ \\
\hline $\begin{array}{l}\text { Keywords: } \\
\text { Fucoidan; } \\
\text { Alginate; } \\
\text { Biorefinery; } \\
\text { Acid Treatment; } \\
\text { Sargassum cristaefolium }\end{array}$ & $\begin{array}{l}\text { brown alga Sargassum cristaefolium. Box Behnken Design (BBD) from } \\
\text { Response Surface Methodology (RSM) was established to understand the } \\
\text { effects of temperature, time and } \mathrm{pH} \text { in acid treatment on the fucoidan yield and } \\
\text { multiple-response alginate as follows: yield, intrinsic viscosity, and molecular } \\
\text { weight. The experimental results revealed that temperature, time and } \mathrm{pH} \\
\text { significantly affected fucoidan yield, alginate yield, intrinsic viscosity, and } \\
\text { molecular weight of alginate. The optimum acid treatment was found at } \\
\text { temperature } 33.75^{\circ} \mathrm{C} \text {, time } 58.22 \mathrm{~min} \text {, and } \mathrm{pH} 3.07 \text {, resulting in fucoidan yield } \\
1.22 \pm 0.068 \% \text {, alginate yield } 29.85 \pm 0.24 \% \text {, intrinsic viscosity } 409.72 \pm 8.23 \\
\mathrm{ml} / \mathrm{g} \text { and molecular weight } 194.08 \pm 3.77 \mathrm{kDa} \text { with the desirability value } 0.805 \text {. }\end{array}$ \\
\hline
\end{tabular}

\section{Introduction}

Brown algae is inarguably one of important sources for polysaccharides, e.g. fucoidan and alginate, with different physicochemical properties (Rioux et al., 2007; Ale et al. 2011a; Torres et al., 2007; Draget and Taylor, 2011). Alginate derived from brown algae is thermostable component, which is widely applied in a variety of industries as thickener, emulsifier, stabilizer, and gelling agent (Poncelet et al. 1999; Gomez et al. 2009; Rahelivao et al. 2013; Sellimi et al. 2015), while it is also massively used in food supplementation, pharmaceutical industry (producing slow-release characteristics), and antitumor (Sousa et al. 2007; Moebus et al. 2012; Jensen et al. 2012). Fucoidan isolated from brown seaweed is also reported capable of exerting beneficial health effects mainly on antitumor, anticancer, antiinflammation, and immunomodulator (Asker et al., 2007; Ye et al. 2008; Kim et al. 2010; Ale et al. 2011b; Costa et al., (2011).

Although seaweed is industrially important, the processing has been currently hindered by some serious constraints, mainly related to low efficiencies and huge amount of waste. To deal with this, the use of integrated biorefinery for producing various products could gradually eliminate the mentioned constraints, while also rising economic benefits (Lorbeer et al. 2015). Such biorefinery processing is greatly possible for brown algae due to presence of fucoidan and alginate with existing or future potential applications (Jung et al. 2013; Ruiz et al. 2013). The parallel processing technology for producing fucoidan and alginate from brown algae could be a great opportunity in biorefinery industry (Sugiono and Ferdiansyah, 2019).

In general, acid treatment was applied to extract fucoidan and alginate from brown algae. It enables to induce destruction of cell walls, hydrogen bond cleavage, and solubilization of 
extracted fucoidan (Kim et al. 2010; Ale et al. 2012; Ermakova et al. 2011; Sugiono et al. 2014), while the acid also simultaneously plays role in converting alginate-salts to alginateacids, avoiding them from production of insoluble contaminants (Myklestad, 1968; Arvizu et al. 2007). During extraction of alginate, acid treatment serves to remove contaminants (fucoidan, laminaran and polyphenol) and produce alginate-acids which then increase their extractability using sodium carbonate (Hernandez-Carmona et al. 1999; Torres et al. 2007; Gomez et al. 2009; Sellimi et al. 2015; Rahelivao et al. 2013; Fertah et al. 2014; Sugiono et al. 2019a). Based on this mechanism, acid treatment becomes a basic principle for sequential biorefinery in extraction of fucoidan and pre-extraction of alginate.

Previous studies have reported the application of acid treatment for sequential extraction of fucoidan and alginate with regard to characterization of the components (Rioux et al. 2007), but their works were not exclusively directed to biorefinery processing. Therefore, the use of acid treatment with optimum levels allows us to perform biorefinery processing for extracting fucoidan and alginate from brown seaweed, resulting in high yield and quality. In low acid concentration, the yield was also poor; on the other hand, the excessive level of acid would degrade alginate structure, causing reduction of its viscosity. This present work aimed to determine optimum level of $\mathrm{pH}$, temperature, and time in the acid treatment for isolating fucoidan and alginate from brown alga Sargassum cristaefolium with regard to biorefinery industry.

\section{Materials and methods}

\subsection{Materials and reagents}

Brown algae Sargassum cristaefolium was obtained from Poteran Island in Sumenep, Madura, and collected in Desember 2018. Chemicals (distilled water, $\mathrm{HCl} 37 \%, \mathrm{NaOH}$, ethanol $99.8 \%, \mathrm{Na}_{2} \mathrm{CO}_{3}$ ) for extraction and analyses were analytical grade.

\subsection{Sequential extraction of fucoidan and alginate}

\subsubsection{Pre-treatment of brown algae}

Brown algae was washed using fresh water, dried, ground, and sieved at 60 mesh (Sugiono et al. 2014). The powder was then soaked in a solution containing ethanol: $\mathrm{CHCl}_{3}$ : distilled water $(4: 2: 1)$, stirred overnight to remove phenol and protein. Last, the mixture was washed and dried at $45{ }^{\circ} \mathrm{C}$ for $6 \mathrm{~h}$ (Ale et al. 2012).

\subsubsection{Fucoidan extraction}

The pre-treated algae $(7.5 \mathrm{~g})$ was added with $\mathrm{HCl}(1: 20, \mathrm{~b} / \mathrm{v} ; \mathrm{pH} 1-5)$ and incubated in a shaking waterbath at $25-45{ }^{\circ} \mathrm{C}$ for $30-90$ min. Subsequently, vacuum filtration was used to separate residue (A) from filtrate. The filtrate was mixed with ethanol $96 \%(1: 2, \mathrm{v} / \mathrm{v})$ and left overnight at room temperature until producing precipitate. Fucoidan was collected following centrifugation at $7000 \mathrm{rpm}$ for $10 \mathrm{~min}$, and dried using vacuum dryer at $45^{\circ} \mathrm{C}$ for $18 \mathrm{~h}$ (Ale et al. 2012).

\subsubsection{Alginate extraction}

Residue A (collected from previous process) was added with $\mathrm{Na}_{2} \mathrm{CO}_{3} 2.5 \%$ (1:20, $\mathrm{b} / \mathrm{v}$ ) and incubated in a shaking waterbath at 70 ${ }^{\circ} \mathrm{C}$ for $2 \mathrm{~h}$, then followed by filtration to collect filtrate. The filtrate was centrifuged at $5000 \mathrm{rpm}$ for $10 \mathrm{~min}$, mixed with ethanol $96 \%(1: 2, \mathrm{v} / \mathrm{v})$ and filtered after incubation for $2 \mathrm{~h}$. The alginate was washed twice using ethanol $70 \%$ and $96 \%$, respectively, filtered and dried using vacuum dryer at $45{ }^{\circ} \mathrm{C}$ for $24 \mathrm{~h}$. Ultimately, the dried alginate was ground and sieved at 60 mesh (Gomez et al. 2009).

\subsection{Experimental design}

Box-Behnken Design in Response Surface Methodology (RSM) was used, consisting of 3 variables, i.e. temperature $\left(\mathrm{X}_{1}: 25,35,45^{\circ} \mathrm{C}\right)$, time $\left(\mathrm{X}_{2}: 30,60,90 \mathrm{~min}\right)$, and $\mathrm{pH}\left(\mathrm{X}_{3}: 1,3,5\right)$. The coded $( \pm 1$ and 0$)$ and actual of independent variables used in this experiment was presented in Table 1. A totally amounting of 15 experimental runs with three replicates in center 
point (Table 2) (Montgomery, 2005). The center points were fixed according to preliminary study.

Regression analysis and model adjustment at the second order was carried out as follows:

$$
Y=\beta_{0}+\sum_{i=1}^{3} \beta_{i} x_{i}+\sum_{i=1}^{3} \beta_{i i} x_{i}^{2}+\sum_{i=1} \sum \sum_{i<j} \beta_{i j} x_{i} x_{j}
$$

where $\mathrm{Y}=$ response, $\beta_{0}=$ intercept coefficient, $\beta_{i}, \quad \beta_{i i}, \quad \beta_{i j}=$ regression coefficient for linier, quadratic, and interaction, and $x_{i}, x_{j}$, $=$ variables of $\mathrm{pH}$ and temperature, and time $(i \neq j)$.

The data analysis was performed in DesignExpert version 7 software in order to find correlation coefficient (R) and determination coefficient $\left(\mathrm{R}^{2}\right)$, while the significance was set at $\mathrm{P}=0.05$. Accuracy between validation and estimated data by Design Expert was compared using paired sample t-test in Minitab 16 software.

Table 1. Coded and actual of independent variables

\begin{tabular}{|l|c|c|c|}
\hline \multirow{2}{*}{$\begin{array}{c}\text { Independent } \\
\text { variables }\end{array}$} & Symbols & \multicolumn{2}{|c|}{ Variables } \\
\cline { 3 - 4 } & & Coded & Actual \\
\hline Temperature $\left({ }^{\circ} \mathrm{C}\right)$ & $x_{1}$ & -1 & 25 \\
\hline & & 0 & 35 \\
\hline Time (min) & & +1 & 45 \\
\hline & $x_{2}$ & -1 & 30 \\
\hline & & 0 & 60 \\
\hline $\mathrm{pH}$ & & +1 & 90 \\
\hline & $x_{3}$ & -1 & 1 \\
\hline & & 0 & 3 \\
\hline
\end{tabular}

Table 2. Box-Behnken Design from RSM and responses

\begin{tabular}{|c|c|c|c|c|c|c|c|}
\hline \multirow{2}{*}{ No } & \multicolumn{2}{|c|}{ Actual variables } & \multicolumn{3}{c|}{ Responses } \\
\cline { 2 - 8 } & $\begin{array}{c}\text { Temperature } \\
\left({ }^{\circ} \mathrm{C}\right)\end{array}$ & $\begin{array}{c}\text { Time } \\
(\mathrm{min})\end{array}$ & $\mathrm{pH}$ & $\begin{array}{c}\text { Fucoidan } \\
\text { yield } \\
(\%)\end{array}$ & $\begin{array}{c}\text { Alginate } \\
\text { yield } \\
(\%)\end{array}$ & $\begin{array}{c}\text { Intrinsic } \\
\text { viscosity } \\
(\mathrm{ml} / \mathrm{g})\end{array}$ & $\begin{array}{c}\text { Molecular } \\
\text { weight } \\
(\mathrm{kDa})\end{array}$ \\
\hline 1 & 35 & 90 & 1 & 1.50 & 31.12 & 103.15 & 45.42 \\
\hline 2 & 45 & 60 & 1 & 0.50 & 29.90 & 140.78 & 65.86 \\
\hline 3 & 25 & 90 & 3 & 1.10 & 26.21 & 258.20 & 118.79 \\
\hline 4 & 45 & 60 & 5 & 0.10 & 27.23 & 285.22 & 134.55 \\
\hline 5 & 25 & 60 & 1 & 1.20 & 28.10 & 246.60 & 116.12 \\
\hline 6 & 35 & 30 & 5 & 0.12 & 26.32 & 183.44 & 86.72 \\
\hline 7 & 45 & 30 & 3 & 0.15 & 26.80 & 170.11 & 78.79 \\
\hline 8 & 25 & 30 & 3 & 0.05 & 26.48 & 267.00 & 122.98 \\
\hline 9 & 25 & 60 & 5 & 0.11 & 26.13 & 222.95 & 101.99 \\
\hline 10 & 35 & 90 & 5 & 0.13 & 26.74 & 223.00 & 104.44 \\
\hline 11 & 45 & 90 & 3 & 1.30 & 29.98 & 191.00 & 89.66 \\
\hline 12 & 35 & 30 & 1 & 1.20 & 29.85 & 283.00 & 130.62 \\
\hline 13 & 35 & 60 & 3 & 1.21 & 29.80 & 400.11 & 189.57 \\
\hline 14 & 35 & 60 & 3 & 1.32 & 29.54 & 532.07 & 255.29 \\
\hline 15 & 35 & 60 & 3 & 1.12 & 30.21 & 407.00 & 192.94 \\
\hline Pred. & 33.75 & 58.22 & 3.07 & $0.71 \pm 0.43^{\mathrm{a}}$ & $29.63 \pm 0.72^{\mathrm{b}}$ & $448.8 \pm 67.24^{\mathrm{c}}$ & $212.6 \pm 32.26^{\mathrm{d}}$ \\
\hline Valid & 33.75 & 58.22 & 3.07 & $1.22 \pm 0.068^{\mathrm{a}}$ & $29.85 \pm 0.24^{\mathrm{b}}$ & $409.72 \pm 8.23^{\mathrm{c}}$ & $194.08 \pm 3.77^{\mathrm{d}}$ \\
\hline & & & & & & & \\
\hline
\end{tabular}




\subsection{Characterization}

\subsubsection{Yield}

Yield was determined according to ratio of alginate or fucoidan weight over initial weight of brown algae, then multiplied by $100 \%$ (Torres et al. 2007).

\subsubsection{Intrinsic viscosity}

For alginate viscosity, viscometer capillary Ubbelohde (Canon, USA) with capillary diameter of $0.56 \mathrm{~mm}$ was employed at $25^{\circ} \mathrm{C}$. Alginate solution was made by dissolving 30 $\mathrm{mg}$ of alginate in $10 \mathrm{ml}$ of aquabides, stirred for $5 \mathrm{~h}$ at room temperature $\left(25^{\circ} \mathrm{C}\right)$ and diluted at serial concentration of $0.05-0.3 \mathrm{~g} / \mathrm{dL}$ (Chee et al. 2011). Relative viscosity $\eta$ was determined according to ratio of flow time $t$ over flow time for solvent $t_{0}$. Meanwhile, intrinsic viscosity [n] was calculated as follows:

$\begin{array}{ll}\text { Relative viscosity, } & \eta=\frac{\mathrm{t}}{\mathrm{t}_{0}} \\ \text { Specific viscosity, } & \eta_{\mathrm{sp}}=\eta-1 \\ \text { Reduction viscosity, } & \frac{\eta_{s p}}{c}=\frac{\eta-1}{c} \\ \text { Intrinsic viscosity, } & {[\eta]=\lim _{c \rightarrow 0} \frac{\eta_{s p}}{c}}\end{array}$

\subsubsection{Molecular weight}

Molecular weight of alginate was determined according to relationship between averaged intrinsic viscosity and molecular weight. Calculation of molecular weight referred to Mark-Houwink, where $\mathrm{k}=0.023$ $\mathrm{dL} / \mathrm{g}$ and $\mathrm{a}=0.984$ (Clementi et al. 1998). In this case, [ $\eta$ ] represented intrinsic viscosity $(\mathrm{dL} / \mathrm{g})$, while $\mathrm{M}_{\mathrm{w}}$ represented molecular weight (kDa).

$$
[\eta]=k M_{w}^{a}
$$

\section{Results and discussions}

\subsection{Yield of fucoidan}

The results showed that all studied variables showed linear relationship to the yield of fucoidan (Figure 1). The yield seemed to raise as increase in temperature, time, and acidity. The highest fucoidan extract $(1.5 \%)$ was obtained at temperature $45^{\circ} \mathrm{C}$, time $90 \mathrm{~min}$, and $\mathrm{pH}$ 1. This is in accordance with previous result reported by Ale et al. (2012), finding that a high temperature causes swelling of the algae cell wall due to thermal expansion, resulting in enhancement of fucoidan extractability (Sugiono et al. 2014). Meanwhile, the use of low $\mathrm{pH}$ and longer acid treatment enabled to soften cell wall of the algae, which increased solubility of fucoidan in $\mathrm{HCl}$ (Silva et al. 2015). Rodriquez et al. (2011) reported that the increase in temperature and time could improve extractability of fucoidan, then it gradually decreased after reaching the optimum level. Lorbeer et al. (2015) stated that fucoidan yield was higher when extracted under higher temperature and longer extraction time, while the low $\mathrm{pH}$ could destroy fucoidan structure.

\subsection{Yield of alginate}

In this present work, we found that all the variables demonstrated quadratic effects on the alginate yield (Figure 2), ranging from 26.21 $31.12 \%$. This was similarly reported by Silva et al. (2015) and Sugiono et al. (2019a). The yield showed an increase with the increased temperature, longer time, and reduced $\mathrm{pH}$ during pre-extraction with acid treatment. This is understandable since an increase in $\mathrm{pH}$ level and time could enhance conversion of $\mathrm{Ca} / \mathrm{H}$ ions, thereby improving the solubility of alginate in $\mathrm{Na}_{2} \mathrm{CO}_{3}$. In addition, higher temperature and longer exposure to acid treatment noticeably contributed to formation of porous and softened structure in surface of the cell walls, which in turn also enabled to increase extractability of alginate (Sugiono et al. 2018b). Fertah et al. (2014) asserted that alginate extract was relatively increased with the increasing extraction temperature, after this condition it was continuously to decrease due to a degradation of alginate chain molecules. Nevertheless, pre-extraction of algae using acid treatment at $\mathrm{pH} 5$ showed a contrary result. The exchange of $\mathrm{Ca} / \mathrm{H}$ ions was logarithmically in proportional with acid concentration and preextraction time (Mykleasted et al. 1968; Lorbeer et al. 2015). 

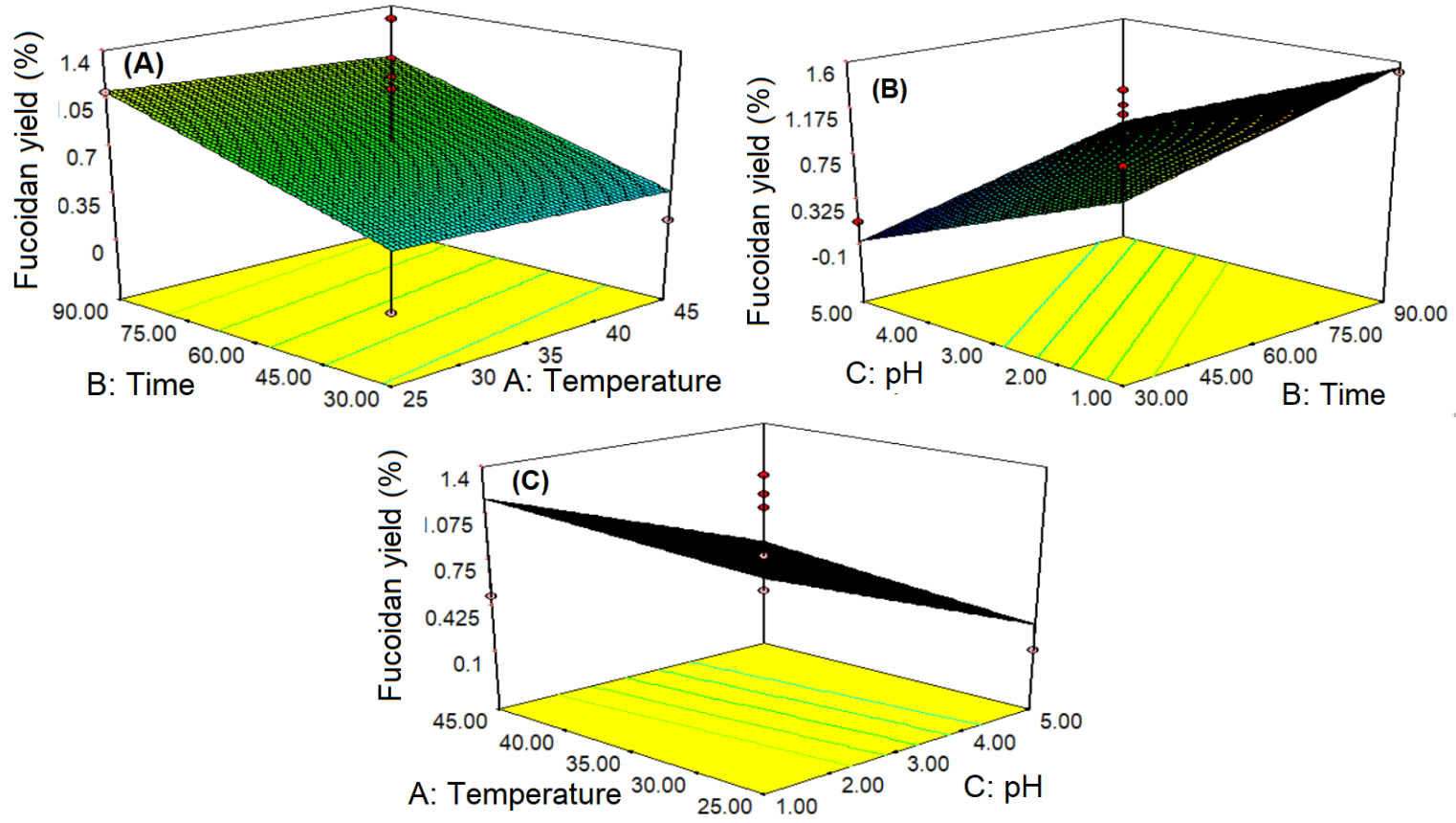

Figure 1. Response surface plots of fucoidan yields from brown algae Sargassum cristaefolium as a function of temperature and time (A), $\mathrm{pH}$ and time (B), temperature and $\mathrm{pH}(\mathrm{C})$.
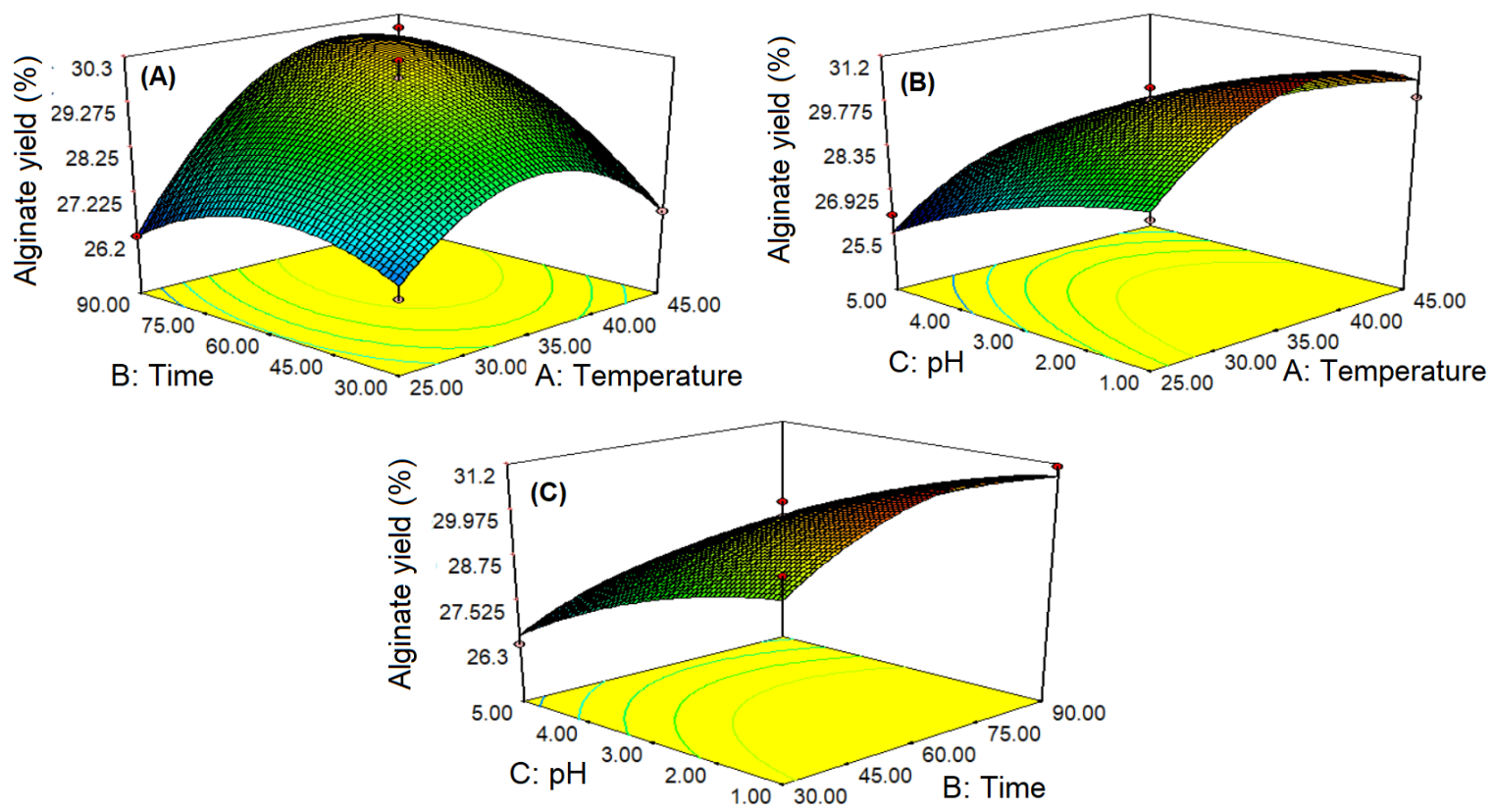

Figure 2. Response surface plots for alginate yield from brown alga Sargassum cristaefolium as a function of temperature and time (A), $\mathrm{pH}$ and temperature (B), $\mathrm{pH}$ and time (C). 

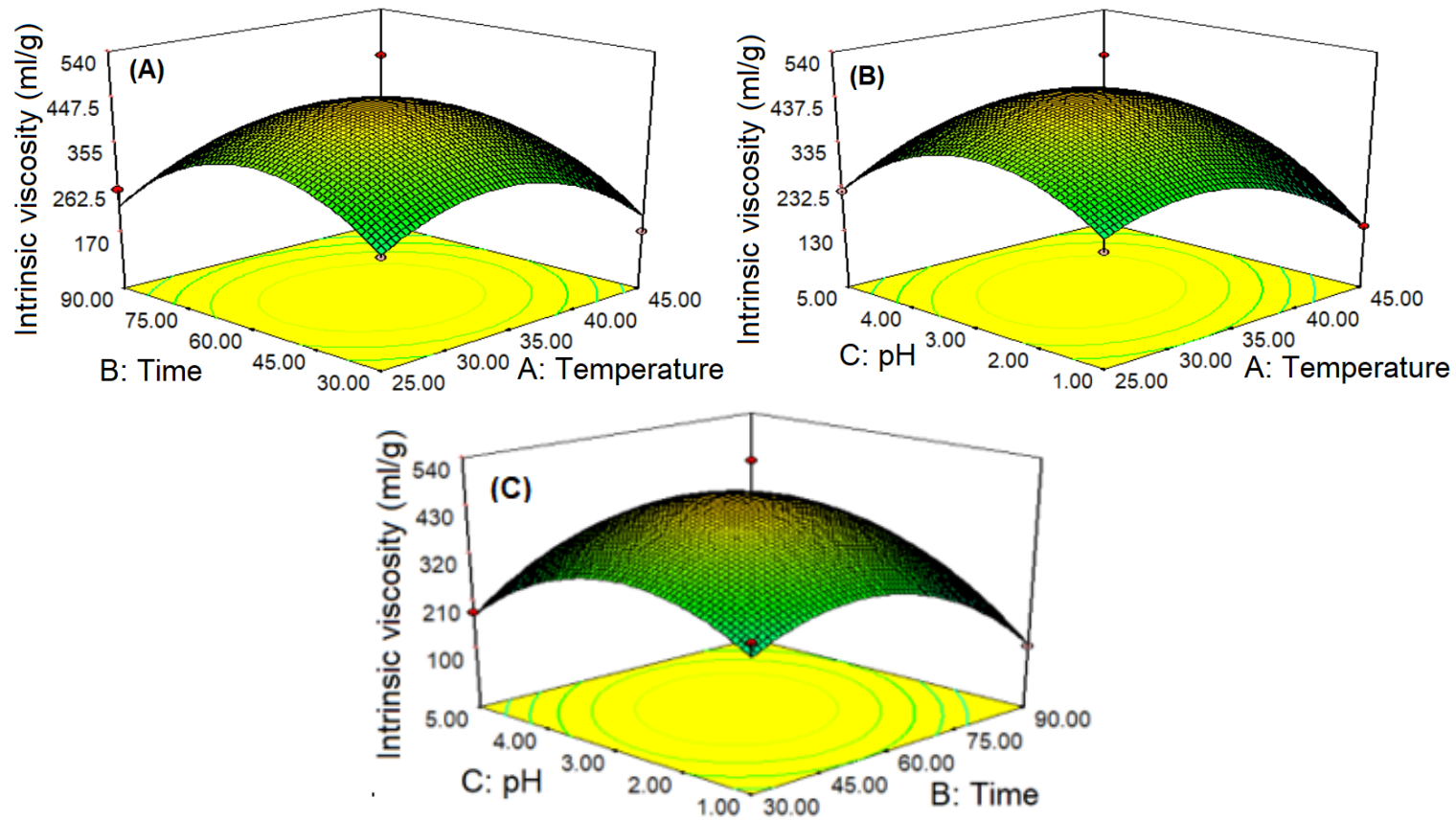

Figure 3. Response surface plots for alginate intrinsic viscosity from brown alga Sargassum cristaefolium as a function of temperature and time (A), $\mathrm{pH}$ and temperature (B), $\mathrm{pH}$ and time (C).
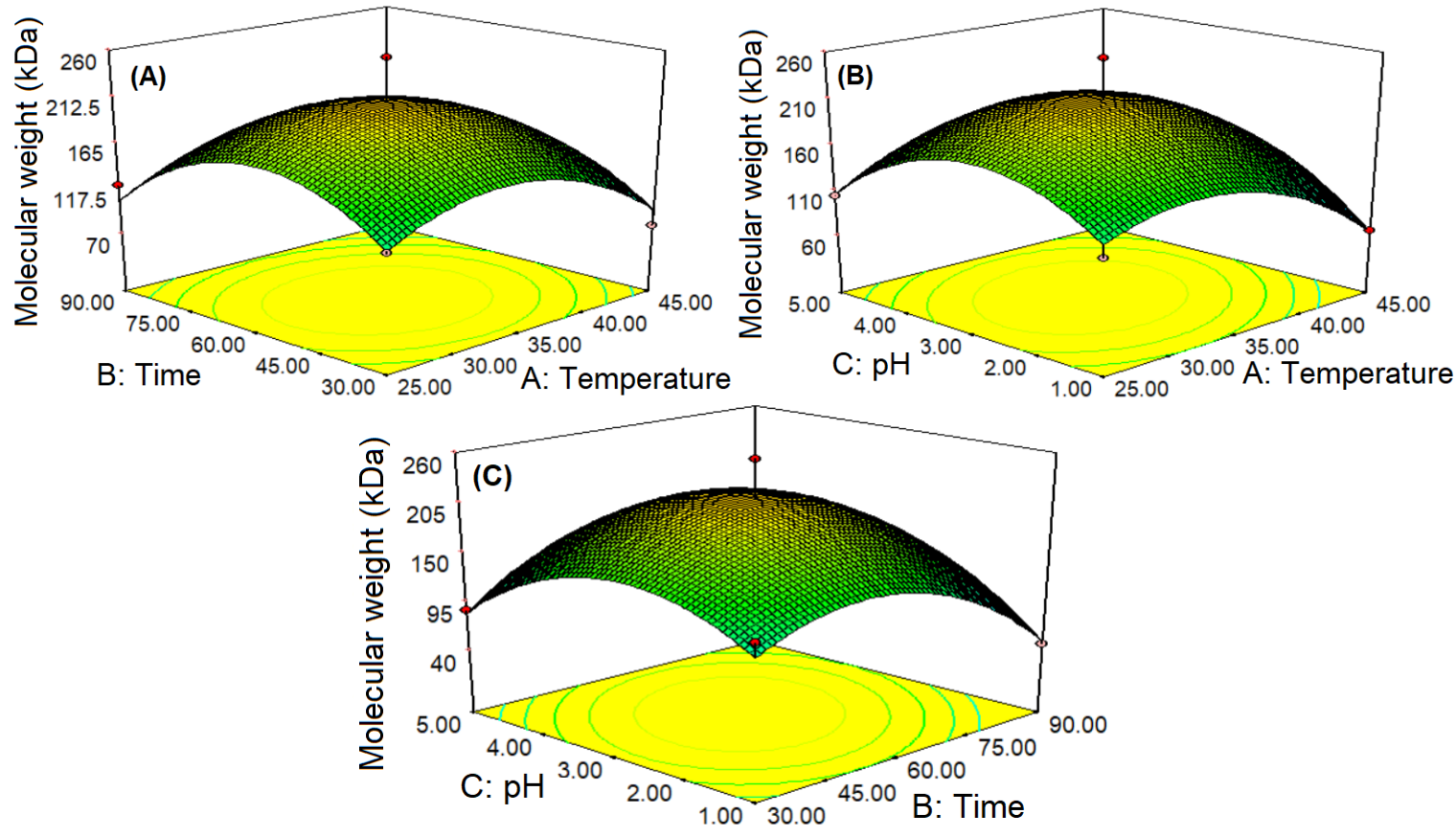

Figure 4. Response surface plots alginate molecular weight from brown alga Sargassum cristaefolium as a function of temperature and time (A), $\mathrm{pH}$ and temperature $(\mathrm{B}), \mathrm{pH}$ and time (C). 


\subsection{Intrinsic viscosity of alginate}

The results demonstrated that difference in temperature, time, and $\mathrm{pH}$ showed quadratic effect on intrinsic viscosity of alginate (Figure 3). An increase in temperature, time, and $\mathrm{pH}$ resulted in a growing viscosity, while it tended to be lower after reaching optimum condition. In this present work, intrinsic viscosity reached $103.15 \mathrm{ml} / \mathrm{g}$ to $446.39 \mathrm{ml} / \mathrm{g}$, which was relatively similar to that reported by Torres et al. (2007), Fenoradosoa et al. (2010) and Rahelivao et al. (2013). The incrementation of alginate intrinsic viscosity was found at $\mathrm{pH} 3$ and time $60 \mathrm{~min}$; however, it showed a decrease at $\mathrm{pH} 1$ and $\mathrm{pH} 5$ in $30-90 \mathrm{~min}$. The rising viscosity is associated with the increasing conversion of $\mathrm{Ca} / \mathrm{H}$ ion exchange occurring at pH 3 within $30-90 \mathrm{~min}$, thus improving the extractability of long-chain alginate.

Additionally, pre-extraction carried out at $\mathrm{pH} 5$ seemed to be ineffective in reducing phenol compounds, in which their existence differently contributed to the increasing cleavage of main polymer chains of alginate during extraction in alkaline condition (Wedlock and Fasihuddin, 1990). Jayasankar (1996) reported that viscosity of alginate was higher after treated with acid compared to that without acid treatment. Meanwhile, extraction at $\mathrm{pH} 1$ could induce degradation of alginate polymer chains (Haug et al. 1963; Smidsrod et al. 1969). Furthermore, the increase in temperature and time during acid treatment would induce cell wall to soften and swell, which remarkably enhanced the extractability of long-chain molecules of alginate (Sugiono and Ferdiansyah, 2018).

\subsection{Molecular weight of alginate}

Present work successfully found that concentration of alginate with high molecular weight tended to increase with a rising temperature, time and acidity (Figure 4). This is augmented by previous studies reported by Torres et al. (2007) and Lorbeer et al. (2015). It is noteworthy that $\mathrm{pH}$ levels in pre-extraction phase strongly caused positive effects on the incrementation of molecular weight, occurring up to $\mathrm{pH} 3$ and time $60 \mathrm{~min}$, although it was then declined at $\mathrm{pH} 1$ and $\mathrm{pH} 5$ within $30-90$ min. At condition of $\mathrm{pH} \mathrm{3}$, temperature $35^{\circ} \mathrm{C}$ and time $60 \mathrm{~min}$, the conversion of $\mathrm{Ca} / \mathrm{H}$ ions was higher, thus escalating the solubility of alginate in $\mathrm{Na}_{2} \mathrm{CO}_{3}$. Myklestad (1968) found that $\mathrm{Ca} / \mathrm{H}$ ion exchange occurred at a higher level with the increase in acidity and time during acid treatment. The higher temperature and longer period of acid treatment was responsible for degradation of cell wall, ultimately contributing to enhanced level of extracted alginate. Sugiono et al. (2018a) mentioned that the extraction of high molecular weight alginate could achieve more desirable results when carried out at high temperature, longer time, and low $\mathrm{pH}$ during pre-extraction acid treatment, after that, it tended to attenuate due to destruction of alginate polymer chains. At low $\mathrm{pH}$, the polymer chain of alginate was destroyed because of $\beta$-elimination and hydrolytic reaction which was catalyzed by proton (Hernandez-Carmona et al. 1999; Silva et al. 2015). However, at $\mathrm{pH}$ 5, molecular weight of alginate was reduced due to oxidative depolymerization triggered by phenolic compounds through auto-oxidation process to release hydrogen peroxide; this free radical was capable of cleaving main chain of alginate molecules (Smidsrod et al. 1963). Wedlock and Fasihuddin (1990) also reported that acid treatment at $\mathrm{pH}$ close to 7 seemed to be less effective in phenolic compound removal; as commonly known, the component was not desired since it promoted degradation of alginate polymers in alkaline extraction stage. Furthermore, previous study found that molecular weight of alginate was higher at acid treatment of $\mathrm{pH} 3.5$ compared to that extracted at pH 5 (Lorbeer et al. 2015).

\subsection{Model accuracy}

Box Behnken Design was used to evaluate the effects of temperature, time, and $\mathrm{pH}$ on yield (fucoidan and alginate), intrinsic viscosity, and molecular weight of alginate. The second order polynomial for biorefinery of sequential extraction was presented in Table 3. 
The model accuracy on each response was evaluated using model significance, lack of fit, and correlation coefficient which are presented in Table 3. The acceptable model was achieved according to following criteria, i.e. significance of $\mathrm{P}<0.05, \quad \mathrm{R}^{2} \geq 0.8$ and lack of fit $>0.1$ (Montgomery, 2005). In this case, the second order polynomial for fucoidan yield and multiple response of alginate fitted entire criteria, suggesting that it is acceptable for predicting optimum response.

\subsection{Optimization and verification}

The optimum condition for extraction was achieved at temperature $33.75{ }^{\circ} \mathrm{C}$, time 58.22 min, $\mathrm{pH}$ 3.07. In such condition, the response was predicted to reach fucoidan yield $0.71 \%$, alginate yield $29.63 \%$, intrinsic viscosity 448.8 $\mathrm{ml} / \mathrm{g}$, and molecular weight $212.6 \mathrm{kDa}$, with desirability value of 0.805 (Figure 5). Desirability ranges from 0 to 1 , in which desirability close to 1.0 indicates that prediction of optimum condition generated by Design Expert possesses high validity (Sugiono et al. 2019b).

The predicted optimum condition was verified using 3 replicates, while the experimental value of response was described as follows: fucoidan yield $1.22 \pm 0.068 \%$, alginate yield $29.85 \pm 0.24 \%$, intrinsic viscosity $409.72 \pm 8.23 \mathrm{ml} / \mathrm{g}$, and molecular weight $194.08 \pm 3.77 \mathrm{kDa}$. Based on paired sample ttest, the data obtained from prediction and validation did not differ significantly $(\mathrm{P}>0.05)$, suggesting that the experimental data showed a desirable suitability with optimum point as predicted by the model.

Table 3. Polynomial models, significance codes and fitting models

\begin{tabular}{|c|c|c|c|c|}
\hline Coefficient & $\begin{array}{c}\text { Fucoidan } \\
\text { yield } \\
(\%)\end{array}$ & $\begin{array}{c}\text { Alginate } \\
\text { yield } \\
(\%)\end{array}$ & $\begin{array}{c}\text { Intrinsic } \\
\text { viscosity } \\
(\mathrm{ml} / \mathrm{g})\end{array}$ & $\begin{array}{c}\text { Molecular } \\
\text { weight } \\
(\mathrm{kDa})\end{array}$ \\
\hline \multicolumn{5}{|l|}{ Intercept } \\
\hline$\beta_{0}$ & +0.74 & +29.85 & +446.38 & +211.46 \\
\hline \multicolumn{5}{|l|}{ Linear } \\
\hline$\beta_{1}$ & $-0.051^{\mathrm{ns}}$ & $+0.87 *$ & $-25.96^{\mathrm{ns}}$ & $-12.33^{\mathrm{ns}}$ \\
\hline$\beta_{2}$ & $+0.31^{\mathrm{ns}}$ & $+0.57 * *$ & $-16.03^{\mathrm{ns}}$ & $-7.61^{\mathrm{ns}}$ \\
\hline$\beta_{3}$ & $-0.49 *$ & $-1.57^{*}$ & $+17.64^{\mathrm{ns}}$ & $+8.34^{\mathrm{ns}}$ \\
\hline \multicolumn{5}{|l|}{ Quadratic } \\
\hline$\beta_{11}$ & - & $+0.86^{\mathrm{ns}}$ & $-8.54^{\mathrm{ns}}$ & $+3.53^{\mathrm{ns}}$ \\
\hline$\beta_{22}$ & - & $-0.17^{\mathrm{ns}}$ & $+42.02^{\mathrm{ns}}$ & $+19.98^{\mathrm{ns}}$ \\
\hline$\beta_{33}$ & - & $-0.21^{\mathrm{ns}}$ & $+54.85^{\mathrm{ns}}$ & $+26.04^{\mathrm{ns}}$ \\
\hline \multicolumn{5}{|l|}{ Cross product } \\
\hline$\beta_{12}$ & - & $-1.57^{\mathrm{ns}}$ & $-99.53 * *$ & $-47.73 *$ \\
\hline$\beta_{13}$ & - & $-0.91 *$ & $-125.27 *$ & $-59.93 *$ \\
\hline$\beta_{23}$ & - & $-0.44 * * *$ & $-122.96 * *$ & $-58.82 *$ \\
\hline \multicolumn{5}{|l|}{ Fitting model } \\
\hline Pvalue & $0.0157 *$ & $0.0062 * *$ & $0.0417 *$ & $0.0423 *$ \\
\hline Lack of Fit & $0.0577^{\mathrm{ns}}$ & $0.1722^{\mathrm{ns}}$ & $0.7914^{\mathrm{ns}}$ & $0.7961^{\mathrm{ns}}$ \\
\hline$R^{2}$ & 0.9558 & 0.9575 & 0.9038 & 0.9032 \\
\hline
\end{tabular}

Equation of the type $Y=\beta_{0+} \beta x_{1+} \beta x_{2}+\beta x_{3}+\beta x_{1} x_{2}+\beta x_{1} x_{3}+\beta x_{2} x_{3}+\beta x_{1} x_{1}+\beta x_{2} x_{2}+\beta x_{3} x_{3}$

Significance codes: $* * *=\mathrm{P}<0.001$

$$
\begin{aligned}
* * & =0.001<\mathrm{P}<0.01 \\
* & =0.01<\mathrm{P}<0.05 \\
\mathrm{~ns} & =\mathrm{P}>0.05
\end{aligned}
$$



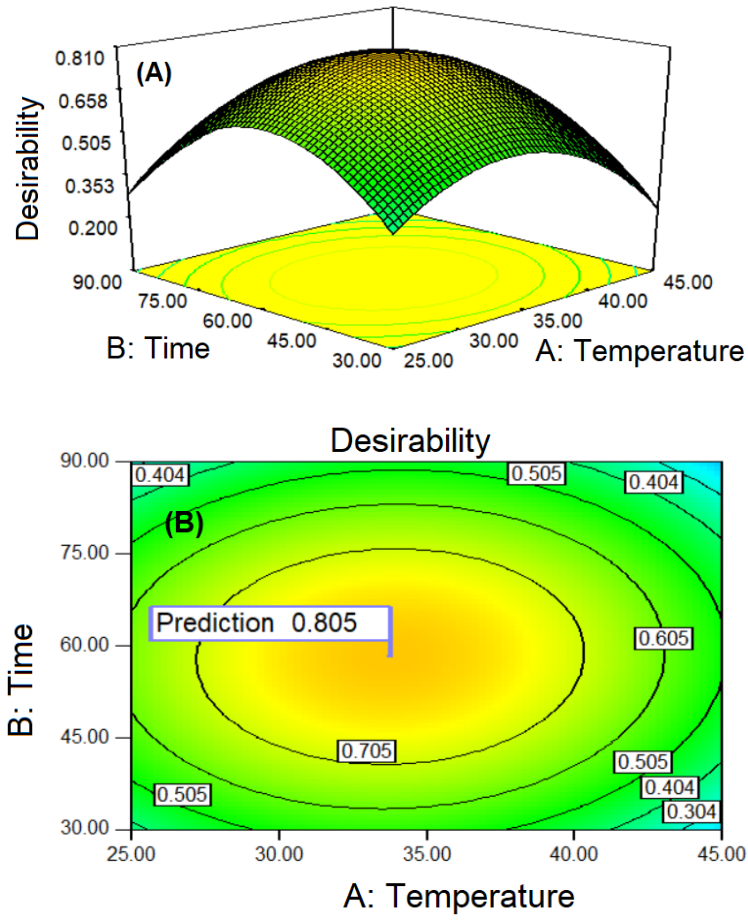

Figure 5. Response surface (A) and contour plot (B) of desirability for optimal points in biorefinery of fucoidan and alginate sequential extraction.

\section{Conclusions}

Biorefinery process for the sequential extraction of brown algae polysaccharides has been developed, this process can produce two products of fucoidan and alginate. The experimental results showed that all studied variables (temperature, time, $\mathrm{pH}$ ) demonstrated linier effects on fucoidan yield, but displayed quadratic effects on alginate yield, intrinsic viscosity, and molecular weight. From the optimization, the best condition for acid treatment would be as follows: temperature $33.75{ }^{\circ} \mathrm{C}$, time $58.22 \mathrm{~min}, \mathrm{pH}$ 3.07. Such condition reached fucoidan yield $1.22 \pm 0.068 \%$, alginate yield $29.85 \pm 0.24 \%$, intrinsic viscosity $409.72 \pm 8.23 \mathrm{ml} / \mathrm{g}$, and molecular weight $194.08 \pm 3.77 \mathrm{kDa}$.

\section{References}

Ale, M. T., Mikkelsen J. D., Meyer A. S., (2011a). Review: Important determinants for fucoidan bioactivity: A Critical Review of Structure-function relations and extraction methods for fucose-containing sulfated polysaccharides from brown seaweeds. Marine Drugs, 9, 2106-2130

Ale, M.T., Maruyana H., Taumachi H., Mikkelsen J. D., Meyer J. D. (2011b). Fucoidan from Sargassum sp. and Fucus vesiculosus reduces cell viability of lung carcinoma and melanoma cells in vitro and activates natural killer cells in mice in vivo. International Journal of Biological Macromolecules, 49,331-336.

Ale, M.T., Mikkelsen J. D., Meyer A.S. (2012). Designed optimization of a single-step extraction of fucose-containing sulfated polysaccharides from Sargassum $s p$. Journal Applied Phycolology, doi:10.1007/s10811-011-9690-3.

Arvizu, D.L., Rodriguez, Y.E., Hernandez, G., Murillo, J.L. (2007). Chemical constituens of Eisenia arborea areschoug from Baja California Sur, Mexico. Investigaciones Marinas Valparaiso, 35, 2, 63-69

Asker, M. S., Mohamed S. Osama, F., Ali F. M. (2007). Chemical structure and antiviral activity of water-soluble sulfated polysaccharides from Sargassum latifolium. Journal Applied Sciences Research, 3(10). 1178-1185.

Chee, Swee-Yong, Wong, P. K., Wong C. L. (2011). Extraction and characterisation of alginate from brown seaweeds (Fucales, Phaeophyceae) collected from Port Dickson, Peninsular Malaysia. Journal Applied Phycology, 23:191-196

Clementi, F., Mancini, M., Moresi, M. (1998). Rheology of alginate from Azotobacter vinelandii in aqueous dispersions. Journal Food Engineering, 36: 51-62

Costa, S.L., Telles C.B.S., Oliveira R.M., Leonardo T.D.B.N., Nednaldo D.D.S., Rafael B.G.C., Mariana S.S.PC., Jailma A.L., Raniere F.M.S., Ivan R.L., Albuquerque, Edda L.I., Hugo A.O.R. (2011). Antioxidant and antiproliferative activities of heterofucans from the seaweed Sargassum filipendula. Marine Drugs, 9, 952-966. 
Draget, Kurt I., Taylor C. (2011). Chemical, Physical and Biological Properties of Alginates and Their Biomedical Implications. Food Hydrocolloids, 25, 2, 251-56.

Ermakova, S, Sokolova R, Kim SM, Um B, Isavakov V., Zvyaginseva T. (2011). Fucoidans from brown seaweeds Sargassum hornery, Eclonia cava, Costaria costata: Structural characteristics and anticancer activity. Applied Biochemical Biotechnology, 164, 841-850.

Fenoradosoa, T.A., Ali G., Delattre C., Laroche C., Petit E., Wadouachi A., Michaud P. (2010). Extraction and characterization of an alginate from the brown seaweed Sargassum turbinarioides Grunow. Journal Applied Phycology, 22, 131-137

Fertah, M., Belfkira A., Dahmane E.M., Taurirte M., Brouillette A., Taurirte M. (2014). Extraction and characterization of sodium alginate from Moroccan Laminaria digitata brown seaweed. Arabian Journal of Chemistry, 5(3), 1878-1888

Gomez, C.G., Lambrcht M.V.P., Lozano J.E., Rinaudo M., Villar M.A. (2009). Influence of the extraction-purification condition on final properties of alginates obtained from brown algae (Macrocystis pyrifera). International Journal of Biological Macromolecules, 44, 365-371

Haug, A., Larsen B., Smidsrod O. (1963). The degradation of alginates at different $\mathrm{pH}$ values. Acta Chemica Scandinavica, 17(5), 1466-1468

Hernandez-Carmona, G., McHugh D.J., ArvizuHiguera D.L., Rodriguez-Montesinos Y.E. (1999). Pilot plant scale extraction of alginate from Macrocystis pyrifera. 1. Effect of pre-extraction treatments on yield and quality of alginate. Journal of Applied Phycology, 10, 507-513

Jayasankar, R. (1993). On the yield and quality of sodium alginate from sargassum wightii (greville) by pre-treatment with chemicals, Seaweed Research and Utilisation, 16 (1\&2), 63-66.
Jensen, M.G., Knudsen J.C., Viereckb N., Kristensen M., Astrup A. (2012). Functionality of alginate based supplements for application in human appetite regulation. Food Chemistry, 132, 823-829

Jung, K. A., Lim S., Kim Y., Park J.M. (2013). Potentials of macroalgae as feedstocks for biorefinery. Bioresource Technology, 135, 182-190

Kim, W.J., Koo Y.K., Jung M.K., Moon H.R., Kim S.M., Synytsya I., Yun-Choi H., H.S.Y., Kim Y.S., Park J.K., Park Y. (2010). Anticoagulating activities of lowmolecular weight fuco-oligosaccharides prepared by enzymatic digestion of fucoidan from the sporophyll of Korean Undaria pinnatifida. Arch Pharmaceutical Research, 33(1), 125-131.

Lorbeer, A. J., J. Lahnstein, V. Bulone, T., Nguyen, Zhang W. (2015). Multipleresponse optimization of the acidic treatment of the brown alga Ecklonia radiata for the sequential extraction of fucoidan and alginate. Bioresource Technology, 197, 302-309

Moebus, K, Siepmann, J., Bodmeier, R. (2012). Novel preparation techniques for alginatepoloxamer microparticles controlling protein release on mucosal surfaces. European Journal of Pharmaceutical Sciences, 45, 358-366

Montgomery, D. C. 2005. Response surface methods and designs. New York. USA: John Willy and Sons. Inc.

Myklestad, S. (1968). Ion-exchange of brown algae. Determination of rate mechanism for calcium hydrogen ion exchange for particles from Laminaria hyperborea and Laminaria digitata. Journal Applied Chemistry, 18, 30-36.

Poncelet, D., Babak V., Dulieu C., Picot A. (1999). A physico-chemical approach to production of alginate beads by emulsification-internal ionotropic gelation. Colloids and Surfaces A: Physicochemical and Engineering Aspects, 155, 171-176

Rahelivao, M. Pascaline, Andriamanantoanina H., Heyraud A., Rinaudo M. (2013). 
Structure and properties of three alginates from madagascar seacoast algae. Food Hydrocolloids, 32(1), 143-46.

Rioux, L. E., Turgeon S. L., Beaulieu M. (2007). Characterization of polysaccharides extracted from brown seaweeds. Carbohydrates polymers, 69, 530-537.

Rodriguez-Jasso, R.M., Mussatto S.I., Pastrana L., Aguilar C.N., Teixeira J.A. (2011). Microwave-assisted extraction of sulfated polysaccharides (fucoidan) from brown seaweed. Carbohydrate Polymers, 86, 1137-1144

Ruiz, H.A., Rosa M. Rodriguez-Jasso, Fernandes B.D., Antonio A., Vicente, Jose A., Teixeira, (2013). Hydrothermal processing, as an alternative for upgrading agriculture residues and marine biomass according to the biorefinery concept: A review. Renewable and Sustainable Energy Reviews, 21, 35-51

Sellimi, S., Younes I., Ayed H.B., Maalej H., Montero V., Rinaudo V, Dahia M., Mechichi T., Hajji M., Nasri M. (2015). Structural, physicochemical and antioxidant properties of sodium alginate isolated from a Tunisian brown seaweed. International Journal of Biological Macromolecules, 72, 358-1367

Silva, M., Gomes, F., Oliveira, F., Morais, S., \& Delerue-matos, C. (2015). Microwaveassisted alginate extraction from Portuguese saccorhiza polyschides - influence of acid pretreatment, World Academy of Science, Engineering and Technology. International Journal of Chemical, Nuclear. Materials and Metallurgical Engineering, 9(1), 30-33

Smidsrod, O., Haug, A., Larsen, B. (1963). Degradation of alginate in the presence of reducing compounds. Acta Chemica Scandinavica, 17(10), 2628-2637

Smidsrod, O., Larsen, B., Painterand T. Haug, A. (1969). The role of intramolecular autocatalysis in the acid hydrolysis of polysaccharides containing 1.4-linked hexuronic acid. Acta Chemica Scandinavica, 23, 1573-1580

Sousa, P.A.A. De, Rocha, M., Pessoa, C.,
Odorico, M., Moraes, D., Costa-lotufo, L.V. (2007). In vivo growth-inhibition of Sarcoma 180 tumor by alginates from brown seaweed Sargassum vulgare, Carbohydrate Polymers, 69, 7-13

Sugiono, Widjanarko S. B., Adisoehono L. (2014). Extraction optimization by response surface methodology and characterization of fucoidan from brown seaweed Sargassum polycystum. International Journal of ChemTech Research, 6(1), 195-205

Sugiono, S., Estiasih T., Masruri M., Widjanarko, S.B. (2018a). Twin screw extruder: Effect condition extrusion process on the intrinsic viscosity of alginate from brown alga Sargassum cristaefolium, Agrosains, 3(1), 279-285

Sugiono, S., Masruri, M., Estiasih, T., Widjanarko, S.B. (2018b). Multipleresponse optimization of the acidic pretreatment of the brown alga Sargassum cristaefolium for the alginate extraction using twin screw extruder. Bioscience research, 15(2), 683-693

Sugiono, S., Ferdiansyah, D. (2018). Fucoidan and alginate sequential biorefinery extraction: Effect of Pre-extraction Acidtreatment Against Intrinsic viscosity of alginate from brown alga Sargassum cristaefolium. Food Science and Technology Journal, 1(2), 44-51

Sugiono, S., Ferdiansyah, D. (2019). Biorefinery sequential extraction of alginate by conventional and hydrothermal fucoidan from brown alga Sargassum cristaefolium. Bioscience Biotechnology Research Communication, 12(4), 894-903

Sugiono, S., Masruri, M., Estiasih, T., Widjanarko S.B. (2019a). Optimization of extrusion-assisted extraction parameters and characterization of alginate from brown algae (Sargassum cristaefolium). Journal of Food Science and Technology, 56 (8), 36873696

Sugiono, S., Masruri, M., Estiasih, T., Widjanarko S.B. (2019b). Structural and rheological characteristics of alginate from sargassum cristaefolium extracted by twin 
screw extruder. Journal of Aquatic Food Product Technology, 28 (9), 944-959

Torres, M.R., Saosa A.P.A., Filho E.A.T.S., Melo D.F., Feitosa J.P.A., Paula R.C.M.D., Lima M.G.S. (2007). Extraction and physochemical characterization of Sargassum vulgare alginate from Brazil. Carbohydrate Research, 342, 2067-2074

Wedlock, D. J., Fasihuddin, B. A. (1990). Effect of formaldehyde pre-treatment on the intrinsic viscosity of alginate from various brown seaweeds. Food Hydrocolloids, 4(1), 41-47.

Ye, H., Wang K., Zhou C., Liu J., Zeng X. (2008). Purification, antitumor and antioxidant activities in vitro of polysaccharides from the brown seaweed Sargassum pallidium. Food Chemistry, 111, 428-432.

\section{Acknowledgment}

Authors wish to acknowledge the funding support from Ministry of Research, Technology and Higher Education, Republic of Indonesia (DRPM DIKTI) with contract number 055/SP2H/LT/K7/2018. 